\title{
SUHU DAN KELEMBABAN TANAH PADA LAHAN REVEGETASI PASCA TAMBANG DI PT ADIMITRA BARATAMA NUSANTARA, PROVINSI KALIMANTAN TIMUR
}

\author{
Karyati $^{1}$, Rani Octaviani Putri ${ }^{2}$, dan Muhammad Syafrudin ${ }^{3}$ \\ ${ }^{1}$ Fakultas Kehutanan, Universitas Mulawarman, Jalan Ki Hajar Dewantara, PO Box 1013 \\ Samarinda, Kalimantan Timur, Indonesia, 75119 Telp. (0541) 735089, 749068 \\ Fax. 735379 \\ ${ }^{2}$ Ecology and Conservation Center for Tropical Studies (Ecositrop), Tanah Merah, \\ Samarinda, Kalimantan Timur, Indonesia, 75123 \\ E-Mail: karyati@fahutan.unmul.ac.id
}

\begin{abstract}
ABSTRAK
Suhu dan Kelembaban Tanah pada Lahan Revegetasi Pasca Tambang di PT Adimitra Baratama Nusantara, Provinsi Kalimantan Timur. Upaya revegetasi pada lahan pasca tambang diharapkan dapat memperbaiki sifat-sifat tanah, memulihkan kesuburan tanah, dan memperbaiki iklim mikro tanah. Tujuan penelitian ini adalah menganalisis karakteristik suhu dan kelembaban tanah pada lahan revegetasi berbeda umur. Suhu dan kelembaban tanah diukur pada kedalaman $10 \mathrm{~cm}$ dan $20 \mathrm{~cm}$ pada revegetasi pasca tambang umur 3, 4, 5, 6, dan 7 tahun. Hasil menunjukkan bahwa suhu tanah tertinggi pada kedalaman $10 \mathrm{~cm}$ dan 20 $\mathrm{cm}$ masing-masing sebesar $27,7^{\circ} \mathrm{C}$ dan $26,6^{\circ} \mathrm{C}$ pada revegetasi umur 3 tahun. Sedangkan suhu tanah terendah pada revegetasi umur 7 tahun pada kedalaman $10 \mathrm{~cm}$ dan $20 \mathrm{~cm}$ berturut-turut sebesar $26,1^{\circ} \mathrm{C}$ dan $24,9^{\circ} \mathrm{C}$. Kelembaban tanah tertinggi adalah $87,8 \%$ (pada kedalaman $10 \mathrm{~cm}$ ) dan $88,0 \%$ (pada kedalaman $20 \mathrm{~cm}$ ) pada lahan revegetasi umur 7 tahun. Ditambahkan, kelembaban tanah terendah pada kedalaman $10 \mathrm{~cm}(81,3 \%)$ dan $20 \mathrm{~cm}(81,5 \%)$ adalah pada kawasan revegetasi umur 3 tahun. Perbedaan umur tanam berpengaruh terhadap fluktuasi iklim mikro, termasuk suhu dan kelembaban tanah pada kedalaman tanah berbeda.
\end{abstract}

Kata kunci : Iklim mikro, kelembaban tanah, pasca tambang, revegetasi, suhu tanah.

\begin{abstract}
Soil Temperature and Humidity at Post Mining Revegetation in PT Adimitra Baratama Nusantara, East Kalimantan Province. The effort of revegetation in post mining area is expected can improve soil properties, restore soil fertility, and stabilize soil micro climate. The objective of this study was to analyze characteristics of soil temperature and humidity in the different ages of revegetation area. Soil temperature and humidity were measured at the depths of $10 \mathrm{~cm}$ and $20 \mathrm{~cm}$ in 3,4,5,6, and 7 years old of post mining revegetation. The result showed that the highest soil temperatures in $10 \mathrm{~cm}$ and $20 \mathrm{~cm}$ depths were $27.7^{\circ} \mathrm{C}$ and $26.6^{\circ} \mathrm{C}$ in 3 years old revegetation. Meanwhile, the lowest soil temperatures in 7 years old revegetation at the depths of $10 \mathrm{~cm}$ and $20 \mathrm{~cm}$ were $26.1^{\circ} \mathrm{C}$ and $24.9^{\circ} \mathrm{C}$, respectively. The highest soil humidities were $87.8 \%$ (at $10 \mathrm{~cm}$ depth) and $88.0 \%$ (at $20 \mathrm{~cm}$ depth) in 7 years old revegetation area. In addition, the lowest soil humidities at the depths of $10 \mathrm{~cm}(81.3 \%)$ and $20 \mathrm{~cm}(81.5 \%)$ were in 3 years old revegetation area. The difference of plant ages influence to micro climate fluctuation, including soil temperature and humidity in the different soil depths.
\end{abstract}

Key words : Micro climate, post mining, revegetation, soil humidity, soil temperature.

\section{PENDAHULUAN}

Pengertian revegetasi adalah usaha untuk memperbaiki dan memulihkan tutupan vegetasi melalui kegiatan penanaman dan pemeliharaan (Permenhut No. P 4/Menhut-II/2011).
Hermawan (2011) menyatakan bahwa tindakan revegetasi dilakukan untuk menanam vegetasi reklamasi pada lokasilokasi yang sudah selesai ditambang, meskipun aktivitas pertambangan secara keseluruhan masih berjalan. Tujuan 
revegetasi adalah untuk meningkatkan produktivitas lahan bekas tambang. Tahapan revegetasi lahan pasca tambang meliputi pembuatan persemaian dan pengadaan bibit, penanaman, serta pemeliharaan tanaman.

Secara umum, suhu dan kelembaban tanah merupakan unsur yang berpengaruh terhadap pertumbuhan tanaman. Menurut Lakitan (1997), suhu tanah akan dipengaruhi oleh jumlah serapan radiasi matahari oleh permukaan tanah. Suhu tanah pada saat siang dan malam sangat berbeda, pada siang hari ketika permukaan tanah dipanasi matahari, udara yang dekat dengan permukaan tanah memperoleh suhu yang tinggi, sedangkan pada malam hari suhu tanah semakin menurun (Rayadin dkk., 2016). Lubis (2007) menambahkan suhu tanah berpengaruh terhadap penyerapan air. Semakin rendah suhu, maka sedikit air yang diserap oleh akar, karena itulah penurunan suhu tanah mendadak dapat menyebabkan kelayuan tanaman. Fluktuasi suhu tanah bergantung pada kedalaman tanah.

Suyono dan Sudarmadi (1997) mendefinisikan kelembaban tanah adalah jumlah air yang tersimpan di antara poripori tanah. Kelembaban tanah sangat dinamis disebabkan oleh penguapan melalui permukaan tanah, transpirasi, dan perkolasi. Arnold (1999) menyebutkan kelembaban tanah memiliki peranan yang penting bagi pemerintah untuk mengetahui informasi seperti potensi aliran permukaan dan pengendali banjir, kegagalan erosi tanah dan kemiringan lereng, manajemen sumber daya air, geoteknik, dan kualitas air. Faktor-faktor yang menentukan kelembaban tanah adalah curah hujan, jenis tanah, dan laju evapotranspirasi, dimana kelembaban tanah akan menentukan ketersediaan air dalam tanah bagi pertumbuhan tanaman (Djumali \& Mulyaningsih, 2014).
PT Adimitra Baratama Nusantara merupakan salah satu perusahaan tambang batubara yang ada di Kabupaten Kutai Kartanegara, Kalimantan Timur yang memiliki kewajiban untuk merehabilitasi areal bekas tambang sesuai dengan UU No. 11 Tahun 1967 tentang Ketentuan-ketentuan Pokok Pertambangan dan Keputusan Menteri Pertambangan dan Energi No.1211.K/008/M.PE/1995 tentang Pencegahan dan Penanggulangan Perusakan dan Pencemaran Lingkungan pada Kegiatan Usaha Pertambangan Umum. Kegiatan revegetasi oleh PT Adimitra Baratama Nusantara (PT ABN) telah dilakukan pada tahun 2010, 2011, 2012, 2013, dan 2014.

Beberapa penelitian tentang suhu dan kelembaban tanah pada kedalaman berbeda di beberapa tipe tutupan lahan telah dilakukan (Arifin, 1993; Beredi, 2010; Karyati \& Ardianto, 2016; Purwoto, 2007). Namun, karakteristik suhu tanah dan kelembaban tanah pada kedalaman berbeda di lahan revegetasi pasca tambang belum banyak dilaporkan. Penelitian ini bertujuan untuk menganalisis suhu dan kelembaban tanah pada kedalaman tanah berbeda di lahan revegetasi pasca tambang berbeda umur.

\section{METODA PENELITIAN}

\subsection{Tempat dan Waktu}

Penelitian ini dilakukan di PT Adimitra Baratama Nusantara (PT ABN), Kecamatan Sanga-sanga, Kabupaten Kutai Kartanegara, Provinsi Kalimantan Timur. Penelitian ini berlangsung selama 5 (lima) bulan dari bulan Februari - Juni 2017. Peta lokasi penelitian di PT ABN disajikan pada Gambar 1 . 


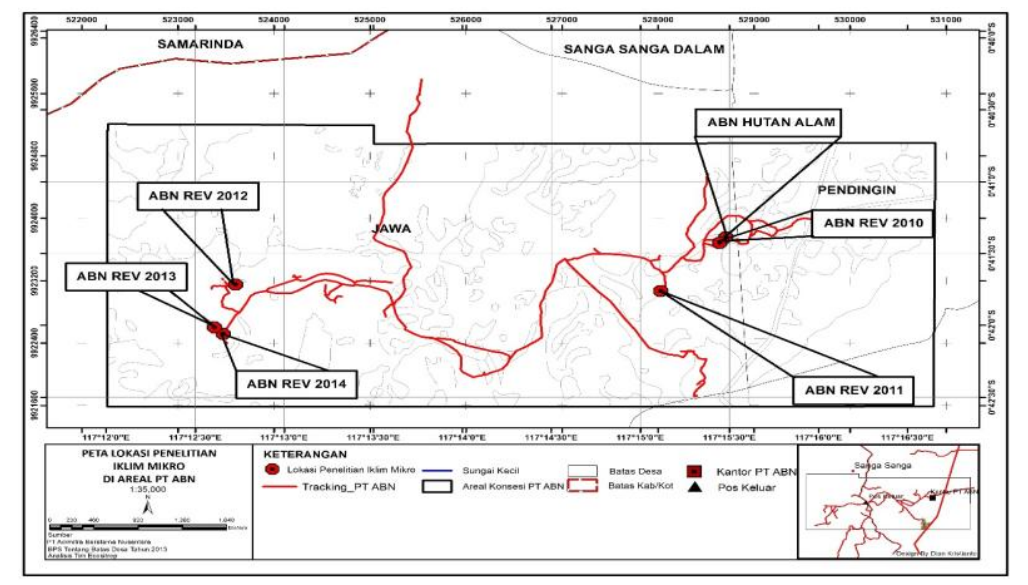

Gambar 1. Peta lokasi penelitian di PT Adimitra Baratama Nusantara, Kecamatan Sanga-sanga, Kabupaten Kutai Kartanegara, Provinsi Kalimantan Timur.

2.2. Bahan dan Alat

Beberapa peralatan dan bahan yang digunakan dalam penelitian ini, antara lain meteran, Global Positioning System (GPS), Environment meter, Reed SD Card Data Logger SD3007, parang, pita pembatas, kamera, dan alat tulis menulis.

\subsection{Parameter Penelitian}

Parameter yang diukur dalam penelitian ini adalah suhu tanah dan kelembaban tanah pada kedalaman tanah berbeda, yaitu $10 \mathrm{~cm}$ dan $20 \mathrm{~m}$. Kedua unsur iklim mikro tersebut diamati pada lahan revegetasi pasca tambang berbeda umur, yaitu 3, 4, 5, 6, dan 7 tahun (masing-masing tahun tanam 2014, 2013, 2012, 2011, dan 2010), serta hutan sekunder sebagai pembanding.

\subsection{Prosedur Penelitian}

2.4.1. Orientasi lapangan dan penentuan lokasi penelitian

Orientasi lapangan bertujuan untuk mengetahui gambaran umum lokasi penelitian. Lokasi penelitian dipilih pada lahan revegetasi pasca tambang yang mewakili umur tanaman berbeda.

2.4.2. Pengukuran suhu dan kelembaban tanah

Suhu dan kelembaban tanah diukur dengan menggunakan alat Environment meter. Pengambilan data dilakukan sebanyak 3 (tiga) kali pengukuran, yaitu pagi hari (pukul 07.00-08.00 WITA), siang hari (pukul 12.00-13.00 WITA), dan sore hari (pukul 16.00-17.00 WITA) selama 5 hari berturutturut. Cara pengukuran suhu dan kelembaban tanah dilakukan dengan menancapkan ujung sensor Environment meter ke dalam tanah pada masing-masing kedalaman berbeda, yaitu $10 \mathrm{~cm}$ dan $20 \mathrm{~cm}$. Pengukuran dilakukan pada lahan revegetasi umur $3,4,5,6$, dan 7 tahun (tahun tanam 2014, 2013, 2012, 2011, dan 2010), serta hutan sekunder sebagai pembanding.

2.4.3. Pengumpulan data sekunder

Data sekunder yang diperlukan dalam penelitian, berupa dokumen profil perusahaan, batas-batas wilayah, letak geografis, kondisi umum lokasi penelitian, dan lainlain. Selain itu, suhu dan 
kelembaban udara pada masingmasing plot penelitian juga diukur Card Data Logger SD3007 dengan menggunakan Reed SD sebagai data pembanding.
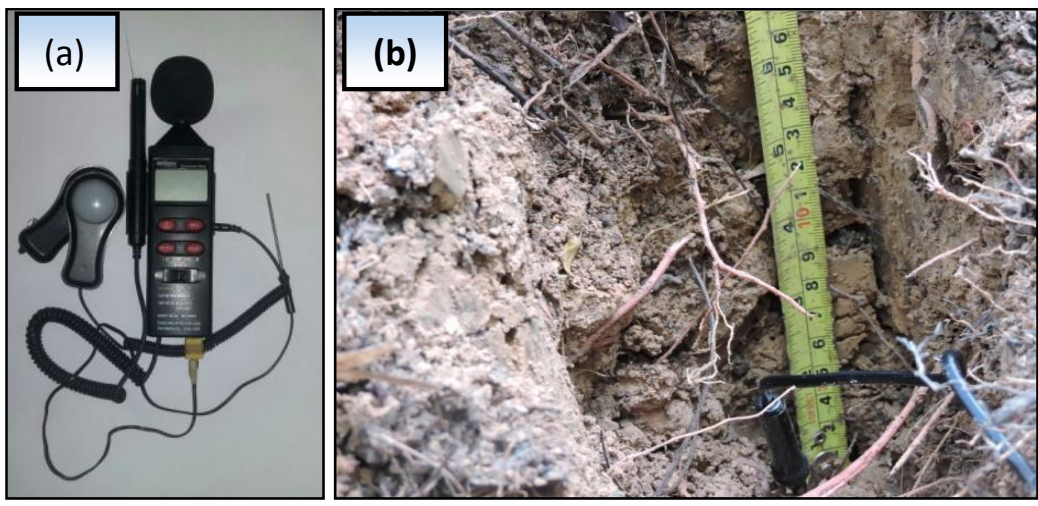

Gambar 2. (a) Alat Environment Meter dan (b) Pengukuran suhu tanah dan kelembaban tanah.

\subsection{Analisis Data}

Suhu tanah dan kelembaban tanah harian rata-rata dihitung dengan menggunakan rumus (Sabaruddin, 2012):

$$
\bar{T}=\frac{2 \mathrm{~T}_{\text {pagi }}+\mathrm{T}_{\text {giang }}+\mathrm{T}_{\text {gore }}}{4}
$$

di mana : $\overline{\mathrm{T}}=$ Suhu tanah harian rata-rata, $\mathrm{T}_{\text {pagi }}=$ Suhu tanah pada pengukuran pagi hari, $\mathrm{T}_{\text {siang }}=$ Suhu tanah pada pengukuran siang hari, dan $\mathrm{T}_{\text {sore }}=\mathrm{Suhu}$ tanah pada pengukuran sore hari.

$$
\overline{R H}=\frac{2 \mathrm{RH}_{\text {pagi }}+\mathrm{RH}_{\text {siang }}+\mathrm{RH}_{\text {sore }}}{4}
$$

di mana: $\overline{\mathrm{RH}}=$ Kelembaban tanah harian rata-rata, $\mathrm{RH}_{\text {pagi }}=$ Kelembaban tanah pada pengukuran pagi hari, $\mathrm{RH}_{\text {siang }}=$ Kelembaban tanah pada pengukuran siang hari, dan $\mathrm{RH}_{\text {sore }}=$ Kelembaban tanah pada pengukuran sore hari.

Hasil pengukuran unsur iklim berupa suhu dan kelembaban tanah pada kedalaman berbeda disajikan secara deskriptif kuantitatif.

\section{HASIL PENELITIAN DAN PEMBAHASAN}

\subsection{Gambaran Umum Lokasi Penelitian}

PT Adimitra Baratama Nusantara (PT ABN) didirikan pada tahun 2004 yang merupakan salah satu perusahaan pertambangan batubara dan produsen batubara termal yang memiliki konsesi dan ijin pertambangan di wilayah Provinsi Kalimantan Timur. PT ABN merupakan anak perusahaan PT Toba Bara Sejahtera. PT ABN memulai kegiatan penambangan batubara pada tahun 2006 dan memulai produksi secara komersial pada tahun 2008. Izin Usaha Pertambangan (IUP) PT ABN mencakup konsensi sekitar 2.990 hektar yang terletak sekitar 30 kilometer sebelah timur Samarinda, ibukota Kalimantan Timur dan dekat dengan muara Sungai Muara Jawa. Wilayah konsesi PT ABN terdiri dari 2 (dua) daerah yang berbeda, yaitu di bagian timur dan barat, dimana keduanya saat ini ditambang dengan menggunakan metode open-pit dengan armada truk dan eksavator.

PT ABN terletak di Kelurahan Jawa, Kecamatan Sanga-sanga, Kabupaten Kutai Kertanegara, Provinsi Kalimantan Timur yang berada di kawasan delta Sungai Mahakam. Luas wilayah Kecamatan Sanga-sanga mencapai $233,4 \mathrm{~km}^{2}$. Secara geografis, 
Kecamatan Sanga-sanga terletak antara $117^{\circ} 01^{\prime}-117^{\circ} 17^{\prime}$ Bujur Timur dan $0^{\circ} 35^{\prime}-0^{\circ} 45^{\prime}$ Lintang Selatan serta berbatasan dengan Kecamatan Anggana di sebelah Utara dan Timur, Kecamatan Muara Jawa di sebelah Selatan, dan Kecamatan Palaran di sebelah Barat. Beberapa jenis yang dijumpai di kawasan hutan sekunder PT ABN, antara lain medang (Actinodaphne glabra), merambung (Vernonia arborea), saninten
(Castanopsis sp.), laban (Vitex pinnata), dan puspa (Schima wallichii).

Kawasan revegetasi pasca tambang PT ABN ditanami beberapa jenis tanaman yang cepat tumbuh (fast growing species) seperti akasia (Acacia mangium), sengon laut (Falcataria mollucana), trembesi (Samanea saman), dan lamtoro (Leucaena leucocephala). Deskripsi areal revegetasi pasca tambang berbeda umur PT ABN ditampilkan pada Gambar 3.

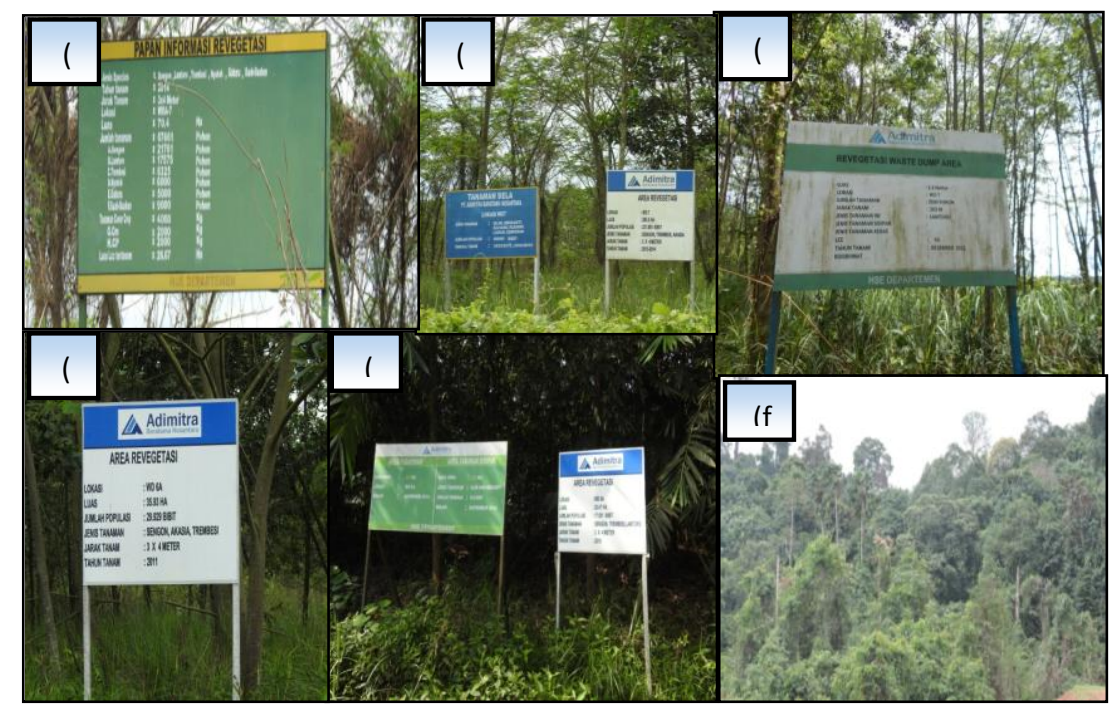

Gambar 3. Lahan (a) Revegetasi umur 3 tahun; (b) Revegetasi umur 4 tahun; (c) Revegetasi umur 5 tahun; (d) Revegetasi umur 6 tahun; (e) Revegetasi umur 7 tahun; (f) Hutan sekunder di PT Adimitra Baratama Nusantara.

3.2. Suhu Tanah dan Kelembaban Tanah di Kawasan Revegetasi Pasca Tambang dan Hutan Sekunder

Secara umum terdapat perbedaan suhu dan kelembaban tanah pada kedalaman 10 dan $20 \mathrm{~cm}$ di areal revegetasi pasca tambang berbeda umur dan hutan sekunder PT Adimitra Baratama Nusantara. Fluktuasi suhu dan kelembaban tanah diduga disebabkan oleh perbedaan ukuran tajuk tanaman karena perbedaan umur tanam pada setiap plot penelitian. Selain itu, fluktuasi suhu dan kelembaban tanah juga terlihat jelas pada kedalaman tanah berbeda yang diamati.

\subsubsection{Suhu Tanah}

Suhu tanah harian rata-rata pada kedalaman $10 \mathrm{~cm}$ di areal revegetasi pasca tambang PT ABN berkisar antara $26,1^{\circ} \mathrm{C}-27,7^{\circ} \mathrm{C}$. Suhu tanah pada kedalaman $10 \mathrm{~cm}$ terendah diukur pada lahan revegetasi umur 7 tahun $\left(26,1^{\circ} \mathrm{C}\right)$, sedangkan suhu tanah tertinggi pada revegetasi umur 3 tahun $\left(27,7^{\circ} \mathrm{C}\right)$. Sebagai pembanding, suhu tanah rata-rata pada kedalaman $10 \mathrm{~cm}$ di hutan sekunder PT ABN adalah $25,9^{\circ} \mathrm{C}$. Suhu tanah ratarata pada kedalaman $10 \mathrm{~cm}$ dan $20 \mathrm{~cm}$ di areal revegetasi pasca tambang berbeda 
umur dan hutan sekunder PT ABN disajikan pada Tabel 1.

Tabel 1. Suhu tanah rata-rata pada kedalaman $10 \mathrm{~cm}$ di lahan revegetasi pasca tambang berbeda umur dan hutan sekunder PT Adimitra Baratama Nusantara

\begin{tabular}{ccccccc}
\hline \multirow{2}{*}{$\begin{array}{c}\text { Tanggal } \\
\text { Pengukuran }\end{array}$} & \multicolumn{5}{c}{ Suhu Tanah $\left({ }^{\circ} \mathrm{C}\right)$ pada kedalaman $10 \mathrm{~cm}$} \\
\cline { 2 - 6 } & $\begin{array}{c}\text { Revegetasi } \\
\text { 3 tahun }\end{array}$ & $\begin{array}{c}\text { Revegetasi } \\
\text { 4 tahun }\end{array}$ & $\begin{array}{c}\text { Revegetasi } \\
\text { 5 tahun }\end{array}$ & $\begin{array}{c}\text { Revegetasi } \\
\text { 6 tahun }\end{array}$ & $\begin{array}{c}\text { Revegetasi } \\
7 \text { tahun }\end{array}$ & $\begin{array}{c}\text { Hutan } \\
\text { Sekunder }\end{array}$ \\
\hline 18 April 2017 & 27,5 & 26,8 & 26,6 & 26,0 & 26,9 & 25,8 \\
19 April 2017 & 27,7 & 26,8 & 27,1 & 26,1 & 25,6 & 26,2 \\
20 April 2017 & 27,6 & 27,1 & 27,4 & 27,1 & 26,4 & 26,6 \\
21 April 2017 & 27,8 & 27,8 & 27,2 & 26,4 & 25,6 & 25,8 \\
22 April 2017 & 27,7 & 27,3 & 26,5 & 26,3 & 25,8 & 25,2 \\
Rata-rata & 27,7 & 27,2 & 27,0 & 26,4 & 26,1 & 25,9 \\
\hline
\end{tabular}

Keterangan: Revegetasi 3 tahun, 4 tahun, 5 tahun, 6 tahun, dan 7 tahun = Lahan revegetasi yang ditanami pada tahun 2014, 2013, 2012, 2011, dan 2010.

Faktor yang mempengaruhi tinggi rendahnya suhu tanah adalah radiasi sinar matahari dan vegetasi. Pada kawasan revegetasi umur 7 tahun memiliki nilai intensitas cahaya yang lebih rendah dibandingkan dengan nilai intensitas cahaya pada kawasan revegetasi umur 3 tahun. Hal ini diduga karena rendahnya intensitas cahaya yang masuk pada revegetasi umur 7 tahun, sehingga mempengaruhi banyaknya panas matahari yang diserap langsung oleh tanah dan akan mempengaruhi suhu tanah. Hal ini juga terjadi pada hutan sekunder, dimana pada hutan sekunder selain pertautan tajuk vegetasi yang rapat, pada lantai hutan sekunder juga terdapat banyak serasah yang berasal dari vegetasi sekitar.

Proses fotosintesis oleh tanaman melibatkan penggunaan air, pemantulan pancaran yang datang, dan energi, cenderung menurunkan suhu iklim mikro dan secara tidak langsung menurunkan suhu tanah. Kondisi di atas permukaan tanah juga turut mempengaruhi suhu tanah. Tanaman penutup dan serasah dapat membantu menyekat dan mengakibatkan dapat meredam suhu tanah. Karyati dan Ardianto (2016) melaporkan suhu tanah di dalam hutan pada kedalaman $10 \mathrm{~cm}$ adalah berkisar 25,8-27,2 ${ }^{\circ} \mathrm{C}$. Beredi (2010) menyebutkan suhu tanah pada kedalaman $10 \mathrm{~cm}$ di tegakan jati umur 3 tahun berkisar 27,4$28,2^{\circ} \mathrm{C}$, sedangkan pada tegakan jati umur 6 tahun berkisar $26,8-26,0^{\circ} \mathrm{C}$. Kisaran suhu tanah rata-rata pada lahan agroforestri campuran kelapa sawit dan jati sebesar $27,9^{\circ} \mathrm{C}$ pada kedalaman 10 cm (Purwoto, 2007).

Berdasarkan hasil pengukuran, suhu tanah pada kedalaman $20 \mathrm{~cm}$ tertinggi pada areal revegetasi umur 3 tahun $\left(26,6^{\circ} \mathrm{C}\right)$ dan terendah pada revegetasi umur 7 tahun $\left(24,9^{\circ} \mathrm{C}\right)$, sedangkan suhu tanah harian rata-rata hutan sekunder sebesar $24,8^{\circ} \mathrm{C}$. Pengukuran suhu tanah pada kedalaman $20 \mathrm{~cm}$ di lahan revegetasi pasca tambang dan hutan sekunder PT ABN memperlihatkan bahwa semakin dalam tanah, maka daya serap dan daya rambat panas matahari semakin lambat, sehingga semakin dalam tanah, maka suhu tanah semakin rendah. Hasil menunjukkan bahwa fluktuasi suhu tanah terjadi pada kedalaman tanah berbeda $(10 \mathrm{~cm}$ dan 20 $\mathrm{cm})$ dan umur tanaman berbeda $(3,4,5$, 6 , dan 7 tahun). Suhu tanah rata-rata pada areal revegetasi berbeda umur tanam berkisar antara $24,9^{\circ} \mathrm{C}-26,6^{\circ} \mathrm{C}$. Suhu tanah rata-rata pada kedalaman 20 $\mathrm{cm}$ di areal revegetasi pasca tambang berbeda umur dan hutan sekunder PT ABN ditampilkan pada Tabel 2. 
Tabel 2. Suhu tanah rata-rata pada kedalaman $20 \mathrm{~cm}$ di lahan revegetasi pasca tambang berbeda umur dan hutan sekunder PT Adimitra Baratama Nusantara

\begin{tabular}{ccccccc}
\hline Tanggal & \multicolumn{5}{c}{ Suhu Tanah $\left({ }^{\circ} \mathrm{C}\right)$ pada kedalaman $20 \mathrm{~cm}$} \\
\cline { 2 - 6 } Pengukuran & $\begin{array}{c}\text { Revegetasi } \\
\text { 3 tahun }\end{array}$ & $\begin{array}{c}\text { Revegetasi } \\
\text { 4 tahun }\end{array}$ & $\begin{array}{c}\text { Revegetasi } \\
\text { 5 tahun }\end{array}$ & $\begin{array}{c}\text { Revegetasi } \\
\text { 6 tahun }\end{array}$ & $\begin{array}{c}\text { Revegetasi } \\
\text { 7 tahun }\end{array}$ & $\begin{array}{c}\text { Hutan } \\
\text { Sekunder }\end{array}$ \\
\hline 18 April 2017 & 26,4 & 25,7 & 25,5 & 24,9 & 25,8 & 24,7 \\
19 April 2017 & 26,6 & 25,7 & 26,0 & 25,0 & 24,5 & 25,1 \\
20 April 2017 & 26,5 & 26,0 & 26,3 & 26,0 & 25,3 & 25,5 \\
21 April 2017 & 26,7 & 26,7 & 26,1 & 25,3 & 24,5 & 24,7 \\
22 April 2017 & 26,6 & 26,2 & 25,4 & 25,2 & 24,2 & 24,1 \\
Rata-rata & 26,6 & 26,1 & 25,9 & 25,3 & 24,9 & 24,8 \\
\hline
\end{tabular}

Keterangan: Revegetasi 3 tahun, 4 tahun, 5 tahun, 6 tahun, dan 7 tahun = Lahan revegetasi yang ditanami pada tahun 2014, 2013, 2012, 2011, dan 2010.

Pengaruh utama suhu tanah terhadap tanaman, yaitu pada perkecambahan biji, aktivitas mikroorganisme, dan perkembangan penyakit tanaman. Pengaruh lainnya adalah pada aktivitas akar, percepatan dan lamanya pertumbuhan tanaman, serta penyakit-penyakit tanaman (Kartasapoetra, 2006). Suhu tanah di dalam hutan pada kedalaman $20 \mathrm{~cm}$ berkisar sebesar $24,0-25,0^{\circ} \mathrm{C}$ (Karyati dan Ardianto, 2016). Beredi (2010) melaporkan suhu tanah pada kedalaman $20 \mathrm{~cm}$ di tegakan jati umur 3 tahun berkisar $27,6-28,2^{\circ} \mathrm{C}$, sedangkan pada tegakan jati umur 6 tahun berkisar 27,2- $27,6^{\circ} \mathrm{C}$. Ditambahkan, suhu tanah ratarata pada lahan agroforestri campuran kelapa sawit dan jati pada kedalaman 20 $\mathrm{cm}$ adalah sebesar $27,8^{\circ} \mathrm{C}$ (Purwoto, 2007).

\subsubsection{Kelembaban Tanah}

Kelembaban tanah rata-rata pada kedalaman $10 \mathrm{~cm}$ di areal revegetasi pasca tambang PT ABN berkisar antara $81,3-87,8 \%$, sedangkan kelembaban tanah di hutan sekunder sebesar 90,0\%. Tabel 3 menyajikan kelembaban tanah harian rata-rata di areal revegetasi pasca tambang berbeda umur dan hutan sekunder PT ABN selama pengamatan.

Tabel 3. Kelembaban tanah rata-rata pada kedalaman $10 \mathrm{~cm}$ di lahan revegetasi pasca tambang berbeda umur dan hutan sekunder PT Adimitra Baratama Nusantara

\begin{tabular}{lllllll}
\hline \multirow{2}{*}{$\begin{array}{l}\text { Tanggal } \\
\text { Pengukuran }\end{array}$} & \multicolumn{6}{l}{ Kelembaban Tanah (\%) pada kedalaman $10 \mathrm{~cm}$} \\
\cline { 2 - 6 } & $\begin{array}{l}\text { Revegetasi } \\
\text { 3 tahun }\end{array}$ & $\begin{array}{l}\text { Revegetasi } \\
\text { 4 tahun }\end{array}$ & $\begin{array}{l}\text { Revegetasi } \\
\text { 5 tahun }\end{array}$ & $\begin{array}{l}\text { Revegetasi } \\
\text { 6 tahun }\end{array}$ & $\begin{array}{l}\text { Revegetasi } \\
\text { 7 tahun }\end{array}$ & $\begin{array}{l}\text { Hutan } \\
\text { Sekunder }\end{array}$ \\
\hline 18 April 2017 & 83,5 & 83,4 & 86,3 & 85,6 & 88,3 & 90,2 \\
19 April 2017 & 82,1 & 84,0 & 88,3 & 86,6 & 87,7 & 92,2 \\
20 April 2017 & 79,2 & 81,2 & 82,9 & 84,7 & 88,2 & 89,2 \\
21 April 2017 & 80,9 & 82,7 & 84,7 & 86,4 & 88,5 & 88,1 \\
22 April 2017 & 80,9 & 83,3 & 86,7 & 86,9 & 86,5 & 90,3 \\
Rata-rata & 81,3 & 82,9 & 85,8 & 86,0 & 87,8 & 90,0 \\
\hline
\end{tabular}

Keterangan: Revetasi 3 tahun, 4 tahun, 5 tahun, 6 tahun, dan 7 tahun = Lahan revegetasi yang ditanami pada tahun 2014, 2013, 2012, 2011, dan 2010.

Hasil menunjukkan kelembaban tanah terendah pada kedalaman $10 \mathrm{~cm}$ adalah pada lahan revegetasi umur 3 tahun $(81,3 \%)$ dan kelembaban tanah tertinggi pada lahan revegetasi umur 7 tahun (87,8\%). Tinggi rendahnya kelembaban tanah pada lahan revegetasi pasca tambang berbeda umur dan hutan 
sekunder berhubungan dengan tinggi rendahnya hasil pengukuran suhu tanah pada lahan-lahan tersebut. Tingginya kelembaban tanah pada lahan revegetasi umur 7 tahun diduga karena lahan memiliki serasah yang cukup banyak dan tersebar merata di lantai lahan revegetasi. Sebagian besar serasah tersebut berasal dari tanaman Bambu (Bambusa sp.). Hal yang sama dijumpai di hutan sekunder, dimana terdapat serasah cukup tebal pada lantai hutan sekunder. Kelembaban tanah pada kedalaman $10 \mathrm{~cm}$ di hutan sekunder termasuk kategori tinggi (90,0\%).
Keberadaan serasah dapat menjaga tingkat kelembaban pada tanah, karena kandungan air yang tersedia pada lapisan tanah, tidak langsung mengalami penguapan ke udara.

Secara umum, kelembaban tanah rata-rata pada kedalaman $20 \mathrm{~cm}$ di areal revegetasi PT ABN berkisar antara 81,5\% hingga 88,0\%, sedangkan di hutan sekunder sebesar 90,2\%. Kelembaban tanah rata-rata pada kedalaman $20 \mathrm{~cm}$ di areal revegetasi pasca tambang berbeda umur dan hutan sekunder PT ABN ditampilkan pada Tabel 4.

Tabel 4. Kelembaban tanah rata-rata pada kedalaman $20 \mathrm{~cm}$ di lahan revegetasi pasca tambang berbeda umur dan hutan sekunder PT Adimitra Baratama Nusantara

\begin{tabular}{lllllll}
\hline \multirow{2}{*}{$\begin{array}{l}\text { Tanggal } \\
\text { Pengukuran }\end{array}$} & \multicolumn{6}{l}{ Kelembaban Tanah $(\%)$ pada kedalaman $20 \mathrm{~cm}$} \\
\cline { 2 - 7 } & $\begin{array}{l}\text { Revegetasi } \\
\text { 3 tahun }\end{array}$ & $\begin{array}{l}\text { Revegetasi } \\
\text { 4 tahun }\end{array}$ & $\begin{array}{l}\text { Revegetasi } \\
\text { 5 tahun }\end{array}$ & $\begin{array}{l}\text { Revegetasi } \\
\text { 6 tahun }\end{array}$ & $\begin{array}{l}\text { Revegetasi } \\
\text { 7 tahun }\end{array}$ & $\begin{array}{l}\text { Hutan } \\
\text { Sekunder }\end{array}$ \\
\hline 18 April 2017 & 83,6 & 83,5 & 86,4 & 85,6 & 88,6 & 90,5 \\
19 April 2017 & 82,4 & 84,1 & 88,4 & 86,7 & 87,7 & 92,5 \\
20 April 2017 & 79,8 & 82,3 & 83,0 & 84,8 & 88,3 & 89,2 \\
21 April 2017 & 81,0 & 82,8 & 84,8 & 86,5 & 88,6 & 88,3 \\
22 April 2017 & 80,9 & 83,4 & 86,7 & 86,9 & 86,7 & 90,4 \\
Rata-rata & 81,5 & 83,2 & 85,9 & 86,1 & 88,0 & 90,2 \\
\hline
\end{tabular}

Keterangan: Revegetasi 3 tahun, 4 tahun, 5 tahun, 6 tahun, dan 7 tahun = Lahan revegetasi yang ditanami pada tahun 2014, 2013, 2012, 2011, dan 2010.

Pengamatan menunjukkan bahwa kelembaban tanah tertinggi pada kedalaman $20 \mathrm{~cm}$ adalah pada areal revegetasi umur 7 tahun $(88,0 \%)$, sedangkan kelembaban tanah terendah pada areal revegetasi umur 3 tahun $(81,5 \%)$. Hasil pengukuran pada kedalaman $20 \mathrm{~cm}$, semakin dalam tanah, maka kelembaban tanahnya semakin tinggi. Hal ini akan berpengaruh terhadap pertumbuhan tanaman. Prentice (1992) menyatakan bahwa curah hujan dan evepotranspirasi potensial berpengaruh terhadap perkembangan dan pertumbuhan secara tidak langsung, melalui pengaruhnya terhadap kelembaban tanah. Setiap jenis tanaman memiliki respon yang unik terhadap variasi pada berbagai aspek iklim tersebut. Ringkasan hasil penelitian terdahulu tentang suhu dan kelembaban tanah pada beberapa tipe tutupan lahan disajikan pada tabel berikut. 
Tabel 5. Suhu dan kelembaban tanah pada beberapa tipe tutupan lahan di Kalimantan Timur

\begin{tabular}{|c|c|c|c|c|}
\hline Lokasi & $\begin{array}{l}\text { Tipe penutupan } \\
\text { lahan }\end{array}$ & Unsur iklim/cua & & Peneliti (Tahun) \\
\hline \multirow{4}{*}{$\begin{array}{l}\text { Taman Bukit Soeharto, } \\
\text { Samarinda-Balikpapan }\end{array}$} & \multirow{2}{*}{ Hutan terbakar } & $\mathrm{T}\left({ }^{\circ} \mathrm{C}\right)$ & 26,45 & \multirow{4}{*}{ Arifin (1993) } \\
\hline & & Ts $10 \mathrm{~cm}\left({ }^{\circ} \mathrm{C}\right)$ & 28,34 & \\
\hline & \multirow{2}{*}{ Hutan tidak terbakar } & $\mathrm{T}\left({ }^{\circ} \mathrm{C}\right)$ & 25,05 & \\
\hline & & Ts $10 \mathrm{~cm}\left({ }^{\circ} \mathrm{C}\right)$ & 25,23 & \\
\hline \multirow{10}{*}{$\begin{array}{l}\text { Lahan agroforestri } \\
\text { (campuran kelapa sawit } \\
\text { dan jati), Desa Loleng, } \\
\text { Kecamatan Kota Bangun, } \\
\text { Kabupaten } \\
\text { Kartanegara }\end{array}$} & \multirow{5}{*}{ Lahan agroforestri } & Ts $0 \mathrm{~cm}\left({ }^{\circ} \mathrm{C}\right)$ & 28,2 & \multirow{10}{*}{ Purwoto (2007) } \\
\hline & & Ts $5 \mathrm{~cm}\left({ }^{\circ} \mathrm{C}\right)$ & 27,9 & \\
\hline & & Ts $10 \mathrm{~cm}\left({ }^{\circ} \mathrm{C}\right)$ & 27,9 & \\
\hline & & Ts $20 \mathrm{~cm}\left({ }^{\circ} \mathrm{C}\right)$ & 27,8 & \\
\hline & & Ts $30 \mathrm{~cm}\left({ }^{\circ} \mathrm{C}\right)$ & 27,4 & \\
\hline & \multirow{5}{*}{ Lahan kritis } & Ts $0 \mathrm{~cm}\left({ }^{\circ} \mathrm{C}\right)$ & 32,75 & \\
\hline & & Ts $5 \mathrm{~cm}\left({ }^{\circ} \mathrm{C}\right)$ & 30,7 & \\
\hline & & Ts $10 \mathrm{~cm}\left({ }^{\circ} \mathrm{C}\right)$ & 29,9 & \\
\hline & & Ts $20 \mathrm{~cm}\left({ }^{\circ} \mathrm{C}\right)$ & 29,7 & \\
\hline & & Ts $30 \mathrm{~cm}\left({ }^{\circ} \mathrm{C}\right)$ & 27,4 & \\
\hline \multirow{10}{*}{$\begin{array}{l}\text { Tegakan jati, Kelurahan } \\
\text { Lempake, } \\
\text { Samarinda }\end{array}$} & \multirow{5}{*}{ Jati umur 3 tahun } & $\mathrm{T}\left({ }^{\circ} \mathrm{C}\right)$ & $24,0-34,0$ & \multirow{10}{*}{ Beredi (2010) } \\
\hline & & Ts $5 \mathrm{~cm}\left({ }^{\circ} \mathrm{C}\right)$ & $27,4-28,6$ & \\
\hline & & Ts $10 \mathrm{~cm}\left({ }^{\circ} \mathrm{C}\right)$ & $27,4-28,2$ & \\
\hline & & Ts $20 \mathrm{~cm}\left({ }^{\circ} \mathrm{C}\right)$ & $27,6-28,2$ & \\
\hline & & Ts $30 \mathrm{~cm}\left({ }^{\circ} \mathrm{C}\right)$ & $27,6-28,0$ & \\
\hline & \multirow{5}{*}{ Jati umur 6 tahun } & $\mathrm{T}\left({ }^{\circ} \mathrm{C}\right)$ & $24,8-32,0$ & \\
\hline & & Ts $5 \mathrm{~cm}\left({ }^{\circ} \mathrm{C}\right)$ & $26,8-28,0$ & \\
\hline & & Ts $10 \mathrm{~cm}\left({ }^{\circ} \mathrm{C}\right)$ & $26,8-27,5$ & \\
\hline & & Ts $20 \mathrm{~cm}\left({ }^{\circ} \mathrm{C}\right)$ & $27,2-27,6$ & \\
\hline & & Ts $30 \mathrm{~cm}\left({ }^{\circ} \mathrm{C}\right)$ & $27,0-27,4$ & \\
\hline \multirow{10}{*}{$\begin{array}{lr}\text { Hutan } & \text { Pendidikan } \\
\text { Fahutan } & \text { Unmul, } \\
\text { Kelurahan } & \text { Lempake, } \\
\text { Kota Samarinda }\end{array}$} & \multirow{10}{*}{ Luar hutan } & $\mathrm{T}\left({ }^{\circ} \mathrm{C}\right)$ & 25,4 & \multirow{10}{*}{$\begin{array}{l}\text { Karyati \& Ardianto } \\
(2016)\end{array}$} \\
\hline & & Ts $5 \mathrm{~cm}\left({ }^{\circ} \mathrm{C}\right)$ & $25,6-27,4$ & \\
\hline & & Ts $10 \mathrm{~cm}\left({ }^{\circ} \mathrm{C}\right)$ & $25,8-27,2$ & \\
\hline & & Ts $20 \mathrm{~cm}\left({ }^{\circ} \mathrm{C}\right)$ & $24,0-25,0$ & \\
\hline & & Ts $30 \mathrm{~cm}\left({ }^{\circ} \mathrm{C}\right)$ & $24,1-24,9$ & \\
\hline & & $\mathrm{T}\left({ }^{\circ} \mathrm{C}\right)$ & 27,4 & \\
\hline & & Ts $5 \mathrm{~cm}\left({ }^{\circ} \mathrm{C}\right)$ & $27,9-31,9$ & \\
\hline & & Ts $10 \mathrm{~cm}\left({ }^{\circ} \mathrm{C}\right)$ & $28,2-31,5$ & \\
\hline & & Ts $20 \mathrm{~cm}\left({ }^{\circ} \mathrm{C}\right)$ & $27,0-28,1$ & \\
\hline & & Ts $30 \mathrm{~cm}\left({ }^{\circ} \mathrm{C}\right)$ & $27,6-28,2$ & \\
\hline \multirow{15}{*}{$\begin{array}{l}\text { PT Adimitra } \text { Baratama } \\
\text { Nusantara, Kelurahan } \\
\text { Sanga-sanga, Kabupaten } \\
\text { Kutai } \quad \text { Kartanegara, } \\
\text { Kaltim }\end{array}$} & \multirow{6}{*}{$\begin{array}{l}\text { Revegetasi umur } 3 \\
\text { tahun }\end{array}$} & $\mathrm{T}\left({ }^{\circ} \mathrm{C}\right)$ & 27,9 & \multirow{15}{*}{ Penelitian ini (2017) } \\
\hline & & Ts $10 \mathrm{~cm}\left({ }^{\circ} \mathrm{C}\right)$ & 27,7 & \\
\hline & & Ts $20 \mathrm{~cm}\left({ }^{\circ} \mathrm{C}\right)$ & 26,6 & \\
\hline & & $\mathrm{RH}(\%)$ & 81,1 & \\
\hline & & RHs $10 \mathrm{~cm}(\%)$ & 81,3 & \\
\hline & & RHs $20 \mathrm{~cm}(\%)$ & 81,5 & \\
\hline & \multirow{6}{*}{$\begin{array}{l}\text { Revegetasi umur } 4 \\
\text { tahun }\end{array}$} & $\mathrm{T}\left({ }^{\circ} \mathrm{C}\right)$ & 27,7 & \\
\hline & & Ts $10 \mathrm{~cm}\left({ }^{\circ} \mathrm{C}\right)$ & 27,2 & \\
\hline & & Ts $20 \mathrm{~cm}\left({ }^{\circ} \mathrm{C}\right)$ & 26,1 & \\
\hline & & $\mathrm{RH}(\%)$ & 82,8 & \\
\hline & & RHs $10 \mathrm{~cm}(\%)$ & 82,9 & \\
\hline & & RHs $20 \mathrm{~cm}(\%)$ & 83,2 & \\
\hline & \multirow{3}{*}{$\begin{array}{l}\text { Revegetasi umur } 5 \\
\text { tahun }\end{array}$} & $\mathrm{T}\left({ }^{\circ} \mathrm{C}\right)$ & 27,4 & \\
\hline & & Ts $10 \mathrm{~cm}\left({ }^{\circ} \mathrm{C}\right)$ & 27,0 & \\
\hline & & Ts $20 \mathrm{~cm}\left({ }^{\circ} \mathrm{C}\right)$ & 25,9 & \\
\hline
\end{tabular}




\begin{tabular}{|c|c|c|c|c|}
\hline \multirow[t]{2}{*}{ Lokasi } & $\begin{array}{l}\text { Tipe } \\
\text { lahan }\end{array}$ & \multicolumn{2}{|l|}{ Unsur iklim/cuaca } & \multirow[t]{2}{*}{ Peneliti (Tahun) } \\
\hline & & $\mathrm{RH}(\%)$ & 85,4 & \\
\hline & & RHs $10 \mathrm{~cm}(\%)$ & 85,8 & \\
\hline & & RHs $20 \mathrm{~cm} \mathrm{( \% )}$ & 85,9 & \\
\hline & \multirow{6}{*}{$\begin{array}{ll}\text { Revegetasi umur } & 6 \\
\text { tahun } & \end{array}$} & $\mathrm{T}\left({ }^{\circ} \mathrm{C}\right)$ & 27,0 & \\
\hline & & Ts $10 \mathrm{~cm}\left({ }^{\circ} \mathrm{C}\right)$ & 26,4 & \\
\hline & & Ts $20 \mathrm{~cm}\left({ }^{\circ} \mathrm{C}\right)$ & 25,3 & \\
\hline & & $\mathrm{RH}(\%)$ & 85,6 & \\
\hline & & RHs $10 \mathrm{~cm}(\%)$ & 86,0 & \\
\hline & & RHs $20 \mathrm{~cm}(\%)$ & 86,1 & \\
\hline & \multirow{6}{*}{$\begin{array}{lll}\text { Revegetasi } & \text { umur } & 7 \\
\text { tahun } & \end{array}$} & $\mathrm{T}\left({ }^{\circ} \mathrm{C}\right)$ & 26,6 & \\
\hline & & Ts $10 \mathrm{~cm}\left({ }^{\circ} \mathrm{C}\right)$ & 26,1 & \\
\hline & & Ts $20 \mathrm{~cm}\left({ }^{\circ} \mathrm{C}\right)$ & 24,9 & \\
\hline & & RH (\%) & 87,6 & \\
\hline & & RHs $10 \mathrm{~cm}(\%)$ & 87,8 & \\
\hline & & RHs $20 \mathrm{~cm}(\%)$ & 88,0 & \\
\hline & \multirow{6}{*}{ Hutan sekunder } & $\mathrm{T}\left({ }^{\circ} \mathrm{C}\right)$ & 26,2 & \\
\hline & & Ts $10 \mathrm{~cm}\left({ }^{\circ} \mathrm{C}\right)$ & 25,9 & \\
\hline & & Ts $20 \mathrm{~cm}\left({ }^{\circ} \mathrm{C}\right)$ & 24,8 & \\
\hline & & RH (\%) & 89,8 & \\
\hline & & RHs $10 \mathrm{~cm}(\%)$ & 90,0 & \\
\hline & & RHs $20 \mathrm{~cm}(\%)$ & 90,2 & \\
\hline
\end{tabular}

Keterangan $: \mathrm{T}=$ Suhu udara; $\mathrm{Ts}=$ Suhu tanah; $\mathrm{RH}=$ kelembaban relatif udara; $\mathrm{RHs}=$ kelembaban relatif tanah.

Faktor lingkungan yang mempengaruhi pertumbuhan berubah secara konstan sepanjang pertumbuhan tanaman. Faktor-faktor tersebut termasuk kelembaban tanah, kuantitas dan kemampuan larut unsur hara mineral, tingkat keasaman tanah, penyakit, insektisida, suhu udara dan tanah, serta penyinaran (Kasperbauer, 1994). Fluktuasi unsur-unsur iklim mikro, berupa suhu dan kelembaban tanah pada kedalaman tanah berbeda dipengaruhi oleh suhu dan kelembaban udara relatif di wilayah tersebut. Perbedaan unsur-unsur iklim terlihat jelas pada jenis tutupan lahan atau tipe vegetasi dominan yang berbeda. Selain pengaruh timbal balik antar unsur iklim/cuaca, fluktuasi unsur iklim/cuaca juga dipengaruhi oleh faktor lingkungan lainnya.

\section{KESIMPULAN}

Suhu tanah tertinggi terukur pada lahan revegatasi umur 3 tahun, sedangkan suhu tanah terendah terukur pada lahan revegetasi umur 7 tahun, baik pada kedalaman tanah $10 \mathrm{~cm}$ maupun $20 \mathrm{~cm}$. Sebaliknya kelembaban udara tertinggi dan terendah masing-masing terjadi pada lahan revegetasi berumur 7 tahun dan 3 tahun. Pertumbuhan tanaman pada revegetasi berbeda umur yang dilakukan pada areal pasca tambang berpengaruh terhadap fluktuasi iklim mikro, terutama suhu dan kelembaban tanah. Variasi suhu dan kelembaban tanah terjadi pada kedalaman tanah dan umur tanaman berbeda. 


\section{UCAPAN TERIMA KASIH}

Penulis memberikan penghargaan kepada manajemen Ecology and Conservation Center for Tropical Studies (Ecositrop) dan PT Adimitra Baratama Nusantara atas bantuan yang telah diberikan selama pengambilan data di lapangan dilakukan.

\section{DAFTAR PUSTAKA}

Arifin, M. 1993. Pengaruh Kebakaran Hutan terhadap Beberapa Aspek Hidrologis dan Mikroklimate di Taman Bukit Soeharto. Proyek Peningkatan Perguruan Tinggi. Jurusan Manajemen Hutan, Fakultas Kehutanan, Universitas Mulawarman. Samarinda.

Arnold, J.E. 1999. Soil Moisture. Tersedia di laman http://www.ghcc.msfc.nasa. gov/landprocess/lp_home.html. Diakses tanggal 04 Februari 2017.

Beredi. 2010. Fluktuasi Suhu Tanah pada Beberapa Kedalaman di Areal Tegakan Jati (Tectona grandis Linn. f.) dengan Kelas Umur yang Berbeda. Fakultas Kehutanan. Universitas Mulawarman. Samarinda (Tidak Dipublikasikan).

Djumali dan Mulyaningsih, S. 2014. Pengaruh Kelembaban Tanah terhadap Karakter Agronomi, Hasil Rajangan Kering dan Kadar Nikotin Tembakau (Nicotiana tabacum L; Solanaceae) Temanggung pada Tiga Jenis Tanah. Balai Penelitian Tanaman Pemanis dan Serat. Berita Biologi. Malang.

Hermawan, B. 2011. Peningkatan Kualitas Lahan Bekas Tambang melalui Revegetasi dan Kesesuaiannya sebagai Lahan Pertanian Tanaman Pangan. Program Studi Agroekoteknologi, Fakultas Pertanian, Universitas Bengkulu. Bengkulu.

Kartasapoetra, A.G. 2006. Klimatologi: Pengaruh Iklim terhadap Tanah dan Tanaman. Bumi Aksara. Jakarta.

Karyati dan Ardianto, S. 2016. Dinamika suhu tanah pada kedalaman berbeda di Hutan Pendidikan Fakultas Kehutanan Universitas Mulawarman. Jurnal Riset Kaltim, 4(1): $1-12$

Kasperbauer MJ. 1994. Light and Plant Development. In PlantEnvironment Interactions (Wilkinson RE, ed.), pp. 83- 123. New York: Marcel Dekker, Inc.

Keputusan Menteri Pertambangan dan Energi No.1211.K/008/M.PE/1995 tentang Pencegahan dan Penanggulangan Perusakan dan Pencemaran Lingkungan pada Kegiatan Usaha Pertambangan Umum.

Lakitan, B. 1997. Dasar-dasar Klimatologi. PT RajaGrafindo Persada. Jakarta.

Lubis, S.K. 2007. Aplikasi Suhu dan Aliran Panas Tanah. Universitas Sumatera. Medan. USU.

Permenhut RI No. P 4/MenhutII/2011tentang Pedoman Reklamasi Hutan.

Prentice, I.C. 1992. Climate Change and Long-term Vegetation Dynamics. In Plant Succession: Theory and Prediction (Glenn-Lewin, D.C., 
Peet, R.K., \& Veblen, T.T., eds.), pp. 293-339. Chapman \& Hall. London.

Purwoto, H. 2007. Studi Tentang Fluktuasi Suhu Tanah pada Kedalaman Berbeda di Areal Agroforestri dan Lahan Kritis. Fakultas Kehutanan. Universitas Mulawarman. Samarinda (Tidak Dipublikasikan).

Rayadin, Y., J. Syamsudin, M. Ayatussurur, N. Qomari, H. Pradesta, A. Priahutama, R.O. Putri. 2016. Pendugaan Biomassa dan Cadangan Karbon. Kerjasama PT Kideco Jaya Agung dan Ecositrop. Samarinda (Tidak Dipublikasikan).
Sabaruddin, L. 2012. Agroklimatologi Aspek-aspek Klimatik untuk Sistem Budidaya Tanaman. Alfabeta. Bandung.

Suyono dan Sudarmadi, 1997. Hidrologi Dasar. Fakultas Geografi. Universitas Gadjah Mada. Yogyakarta.

UU No. 11 Tahun 1967 tentang Ketentuan-ketentuan Pokok Pertambangan. 